\title{
STUDIES ON THE DISTRIBUTION OF BARNACLE LARVAE AND THE BARNACLE FOULING IN THE ESTUARINE AREA OF MUARA KARANG
}

\author{
by \\ KASIJAN ROMIMOHTARTO ${ }^{1}$ ) and OKTO HARYANTO ARINARDI ${ }^{1}$ )
}

\begin{abstract}
Estuary hosts many of the meroplanktonic lives of marine animals, among which are the barnacles.

The study of the seasonal abundance of the barnacle larvae and of the barnacle attachments at Muara Karang during 1975-1976 indicated that barnacle larvae and barnacle attachments occurred throughout the year. However, certain peaks of the larvae abundance and the high densities of attachment were found in certain months of the year. The peaks of larvae distribution were observed in April 1975, June 1975, September 1975, and January 1976. In general the density of the attached barnacles on panels was highest during the period of March - August, and lowest during December-February.

The physical, biological, and sedimentological factors in relation with the distribution of the barnacle larvae and the density of the attached barnacles were discussed. Two governing factors seemed to be the wave and the sediment load.

Relationship between the abundance of the barnacle larvae and the density of attachment was difficult to see.
\end{abstract}

\section{INTRODUCTION}

Estuarine waters are known to host many of the meroplanktonic lives of marine invertebrates and marine fishes, among which are the barnacle larvae. The occurrence of the barnacle larvae needs to be taken into account especially in connection with the problem of fouling, because this can be an indication of the potential barnacle fouling of the area. Although it is sometimes difficult to correlate directly the abundance of the larvae at a certain period with the intensity of barnacle fouling at the following period, the occurrence of barnacle larvae in great abundance may be an indication of high intensity of barnacle fouling.

The occurrence of barnacle fouling in the estuarine area will become one of many problems in the coming future. This is due to the fact that there is a tendency for certain coastal areas, close to the estuary, to be

1) National Institute of Oceanology, Indonesian Institute of Sciences, Jakarta, Indonesia 


\section{KASIJAN ROMIMOHTARTO \& OKTO HARYANTO ARINARDI}

chosen as sites for the establishment of electric steam power generators, for which underwater intake and discharge pipes for cooling water will be constructed. The barnacles then will be taken into serious consideration since they attack underwater construction and the mouth part of the underwater pipe lines as well. This could hinder the normal inflow and outflow of the cooling water needed.

It is surprising to know that although the problems of marine fouling have long been known in Indonesia, the knowledge on the biology of fouling organisms of the Indonesian waters is still very little. There are very few studies made on the fouling organisms in this country.

The present study is intended to contribute to the knowledge on one aspect of the estuarine management which is closely related to the maintenance and operation of electric power generator in this area and at once to contribute to the knowledge of fouling organisms of Indonesia.

\section{MATERIAL AND METHODS}

The areas where the studies were made, beside Muara Karang, were Sumegur Cove in Sunda Strait and Panggang Island off Jakarta Bay. The last two places were chosen for comparison.

The stations which were occupied during the study were situated off Pluit, Jakarta Bay, parallel to the shore. Plankton samplings were made at nine stations (Fig. 1). Regular monthly samplings were done between 8 a.m. to 4 p.m. (West Indonesian Time) from March 1975 to February 1976.

A NORPAC -net which has a mouth-diameter of $45 \mathrm{~cm}$, length of $180 \mathrm{~cm}$, and mesh-aperture of $0.33 \mathrm{~mm}$ was used. At the centre of the net, a TSK flowmeter was mounted. Samplings were done obliquely from near the bottom up to the surface in about six minutes; except for station 1 and station 2, horizontal haul was done in three minutes only due to the shallowness of the waters. The displacement volume was measured according to the method of WICKSTEAD(1965). Every preserved sample was taken, then made up to a known volume $(100 \mathrm{ml})$, and two fractions $(2 \mathrm{X} 2.5 \mathrm{ml})$ were quickly removed by a stempel pipette to a counting tray, and examined under a binocular microscope The organisms were all counted.

The methods used in the study of the barnacle foulings were as follows: Three steel plates $\left(30 \times 30 \mathrm{~cm}^{2}\right)$, three brass plates of the same size, one big pralon pipe $(7.5 \mathrm{~cm}$ diameter; $25 \mathrm{~cm}$ long), one small pralon pipe $(3.65 \mathrm{~cm}$ diameter; $25 \mathrm{~cm}$ long), one copper pipe $(6.4 \mathrm{~cm}$ diameter; $25 \mathrm{~cm}$ long), and one brass pipe ( $2.6 \mathrm{~cm}$ diameter; $25 \mathrm{~cm}$ long) were submerged at each of the 


\section{STUDIES ON THE DISTRIBUTION OF BARNACLE LARVAE}

two stations i.e., station A on the eastern side of the Karang River and station B on the western side of the river (Fig. 1). The panels were embedded to the submerged portion of a bamboo construction built at each station to let them constantly immersed. The steel and brass panels were fixed horizontally and vertically facing sea-shore and east-west directions.

Examination, counting, and measuring were made monthly. Counts were made by using a wooden frame $\left(30 \times 30 \mathrm{~cm}^{2}\right.$ ) gridded into 196 squares ( $2 \times 2$ $\mathrm{cm}^{2}$ ). Ten squares were chosen randomly for each surface of panel. Then all barnacles in each chosen square were counted. The average numbers per square were calculated, multiplied by 225 to produce numbers of barnacle per 900 $\mathrm{cm}^{2}$. For pipes, all attached barnacles on their surfaces were counted. The maximum base-diameter of some barnacles were measured for each surface.

All panels were well cleaned after examination and before resubmersion. This was meant for studying the monthly attachment densities. Fouling organisms other than barnacles, if any, were recorded.

\section{DESCRIPTION OF THE AREA}

There are three different localities chosen for the study, i.e. Muara Karang estuarine area, Sumegur Cove, and Panggang Island. Muara Karang estuarine area is situated at the southwestern part of the Jakarta Bay. The bottom of the area, which is mainly mud and sand, is gently sloping from the beach seaward, reaching a depth of about $8 \mathrm{~m}$ at the northernmost plankton station (Station 9).

Three main rivers, Ciliwung, Karang, and Angke discharge their water into the area through their respective estuaries i.e. Pasar Ikan Canal, Muara Karang, and Muara Angke. Ciliwung River, which passes Sunda Kelapa Harbour, is heavily polluted. The water is blackish in colour with nauseating odour of hydrogen sulphide. Karang River, located between Ciliwung and Angke Rivers, is now a quite busy passage for fishing boats and sand boats. The water is usually also blackish in colour. The flow is mainly governed by the state of the tide. Angke River is bigger compared with the other two rivers and the flow is also stronger. The always brown colour of the water carries a lot of floating matters. The greatest source of this floating materials is originated from the Banjir Canal, a large water channel passes right through the centre of the heavily polluted city.

Along the eastern bank of the estuarine area of Karang River, a generating power plant will be built by PLTU. This area is a reclaimed 
KasiJan Romimohtarto \& OKTO Haryanto ARINardi

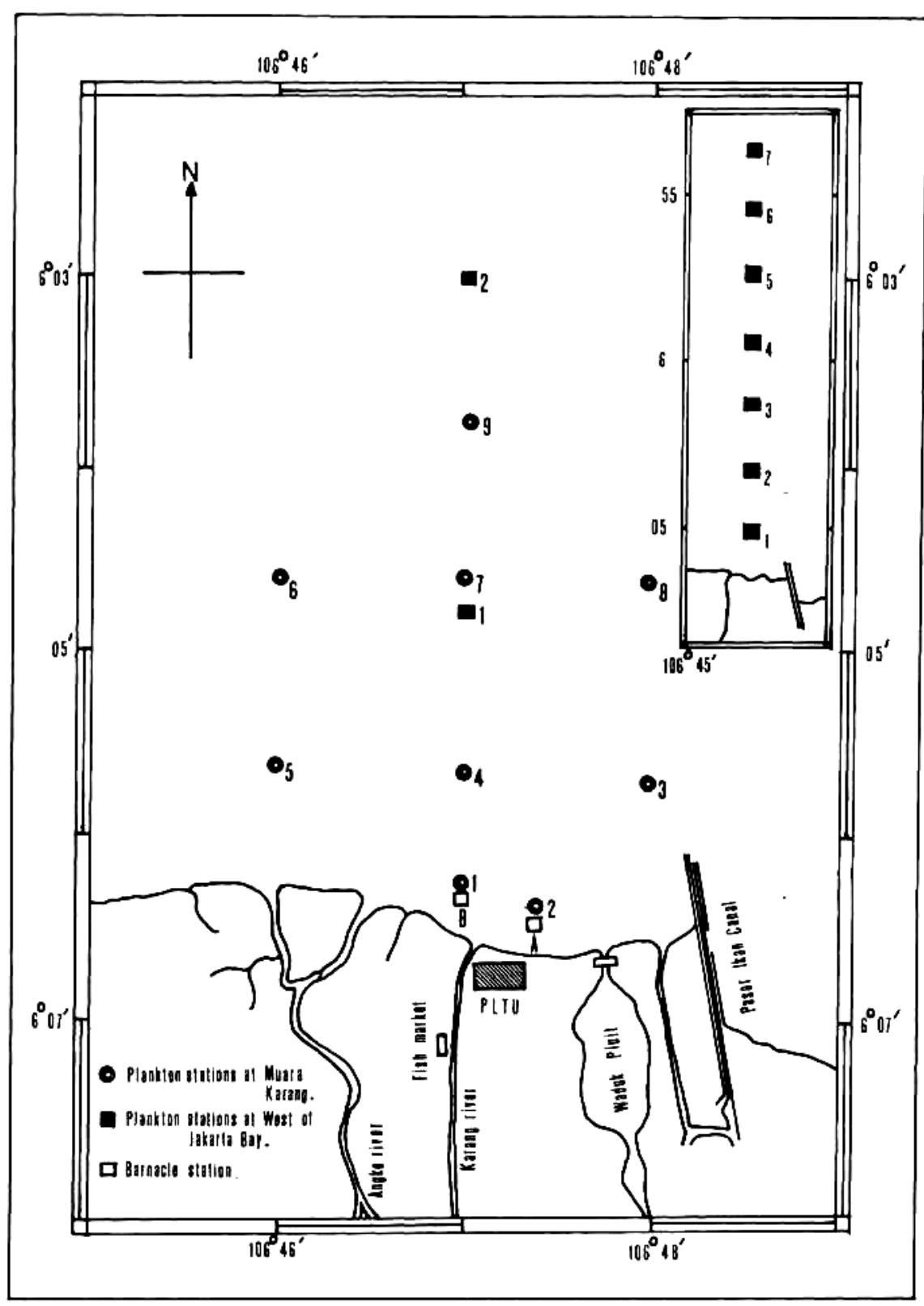

Figure 1. Map of Muara Karang. 


\section{STUDIES ON THE DISTRIBUTION OF BARNACLE LARVAE}

mangrove swamp. Along the other side of the bank is fisherman's village. The area between Muara Angke and Muara Karang is still occupied by "tambaks" (brackish water fish pond). Milkfish and penaeid prawns are reared in these "tambaks".

Sumegur Cove and its surrounding is of different nature. It is situated in the Sunda Strait between $105^{\circ} 56^{\prime} 30^{\prime \prime}-105^{\circ} 59^{\prime} 00^{\prime \prime E}$ and $5^{\circ} 59^{\prime} 00^{\prime \prime}-6^{\circ} 01^{\prime} 00^{\prime \prime} \mathrm{S}$. It is also situated close to the site where the electric generating plant will be constructed. This site is a coastal low-land area bordered in the north-east and south-east by mountainous regions.

Generally the coast consists of fringing coral reef, therefore it is quite irregular in outline. Certain parts are deeply indented forming coves. Three coves are noted in the area investigated. The largest one, situated between the other two, in Sumegur Cove (Fig. 2). This cove is incorrectly known as an estuary with its mouth bordered in the southwest by a land called Muara (=estuary) and in the northeast by a land called Kelapa Dua. However, Sumegur is not an estuary because although the water is turbid, characterizing estuarine condition, the salinity is a characteristic of the open sea, i.e. at least, or even higher than $31 \%$ o.

Sumegur Cove penetrates deep landward, ending in a branching rivulets within vast mangrove swampy area. Mangrove trees such as Rhizophora, Sonneratia and Avicenia corniculatus are common. Salinity as low as $10-$ $12 \%$. was recorded in December from one of the rivulets and from the innermost part of the cove. The bottom of the cove is thickly muddy with big rocks of coral reef origin found here and there, emerging to the surface. These rocks are also found in the swampy area.

Panggang Island, however, is not an estuarine environment. It is located about 25 miles from Sunda Kelapa Harbour and is far from estuarine influence. It is a coral island.

\section{RESULTS AND DISCUSSION}

\section{Abundance and distribution of barnacle larvae}

The barnacle larvae were present in the plankton community for most of the year. They were less in numbers during March 1975 and December 1975 (Figs. 3 \& 4). Four maxima were observed during the period of study i.e. in April 1975, June 1975, September 1975, and January 1976, with highest peak in September 1975 (63,874 ind./1OOO $\left.\mathrm{m}^{3}\right)$. THAM (1953), WiCKSTEAD (1958), and CHuA (1970), who worked on the plankton of 


\section{KASIJAN ROMIMOHTARTO \& OKTO HARYANTO ARINARDI}

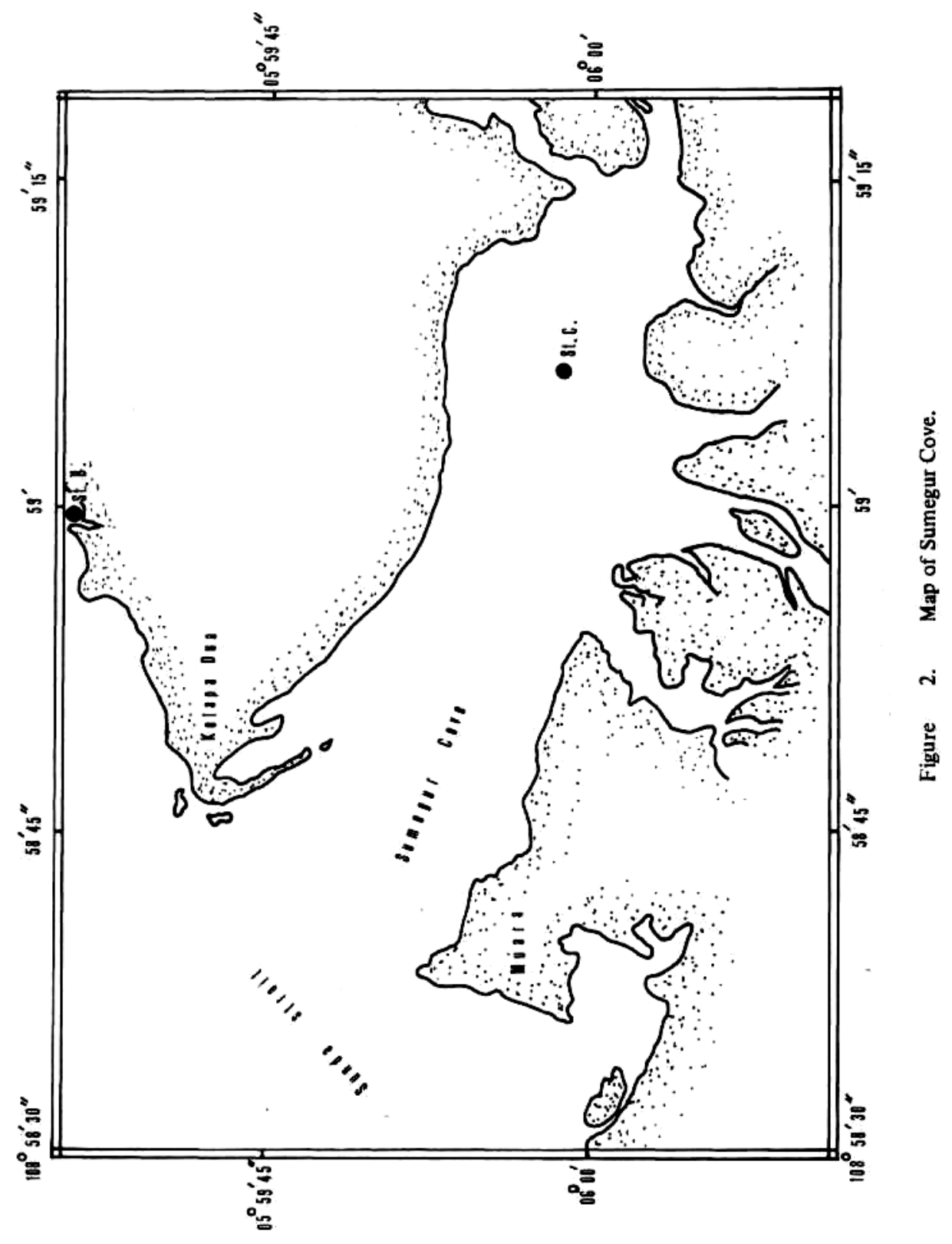




\section{STUDIES ON THE DISTRIBUTION OF BARNACLE LARVAE}

Singapore Straits and Ponggol Estuary, stated that barnacle larvae were observed in the plankton throughout the year though never in large numbers. Unfortunately no detailed observations on the fluctuation in abundance have been done. PRASAD (1954) concluded that barnacle nauplii at the Gulf of Mannar, India, occurred frequently during January-April and August-October. PYEFINCH (1948), who studied the barnacle larvae for four years at Millport, England, reached at a conclusion that the seasonal occurrence of barnacle larvae in the plankton having clearly indicated their abundance during the months of February, March and April.

Compared with the data taken in 1974 (July, August, and September) at Muara Karang waters (LEMBAGA OSEANOLOGI NASIONAL 1974), it is shown that the total numbers of barnacle nauplii in July were nearly similar to the present study. In August 1974, however, the number is greater (28,237 ind./1OOO m³) than that of the present observation $\left(2,896\right.$ ind./10OO $\left.\mathrm{m}^{3}\right)$. It is also surprising to see that cyprids were never found in August 1974, but they formed $41 \%$ of the total barnacle larvae in August 1975, though the sampling in 1974 was done three times every month with ten-day intervals.

Barnacle larvae of the waters around Panggang Island, northwest of Jakarta Bay, appeared only at certain months of the two years of study and never in appreciable quantity. The greatest numbers were during the Transition Periods (October 1971: 6,581 ind./1OOO $\mathrm{m}^{3}$ and April 1973: 5,685 ind./1OOO $\mathrm{m}^{3}$ ). These numbers, however, were smaller than the results of the present investigations. These may be due to the scarcity of the parent stock near Panggang Island waters. Coral reefs do not seem to host attaching barnacles. The scarcity or even the absence of the parent stock in the coral reef area seems to be a common phenomenon. The absence of attached barnacles on panels submerged at the reef area at Cilegon (Fig. 2, St. B) (SOEgIARTO et al 1974) is another example.

During June 1974 to June 1975, there was also a study of zooplankton fluctuations at the west of Jakarta Bay, nearly at the same location with the present observations. The sampling stations, however, were perpendicular to the coast and the samplings were done by vertical haul (Fig. 1). The results showed three maxima of barnacle larvae, namely in August 1974, December 1974 and April 1975. The minima were found in October 1974, February 1975 and June 1975.

PYEFINCH (1948) surmissed that for Balanus balanoides, the full development of the early 'brood' was appreciably upset by the abundance of diatoms in the water. BARNES (1950), however, did not agree with this conjecture. The present results are also in agreement with BARNES'.This can 


\section{KASIJAN ROMIMOHTARTO \& OKTO HARYANTO ARINARDI}

be shown by the fact that although in June 1975 there was a bloom of Coscinodiscus and Hemidiscus, the barnacle larvae were also present in abundance. It is also surprising to know that during the blooming of Noctiluca sp. in September 1975, the nauplii reached a peak (Fig. 3). It seems that the abundance of barnacle nauplii of this area were not fully influenced by the biological factor, but most likely governed by the breeding season of the parent stock nearby Muara Karang, at least for a short period. For a longer period, however, the currents are the important agents in the transportation of organisms and may profoundly affect the distribution of barnacle larvae. FLEMMING (1948) stated that the currents are generally more rapid in shallow waters and in the proximity of land boundaries. Therefore, the possibility of surface currents bringing into or carrying away water masses from the area investigated resulting an abrupt change in the plankton, cannot be rejected.

MOORE (1935) citing JOHNSTONE ef al (1924) stated that there was an interval between the maxima for the nauplius and the cypris stages for nearly two months in Port Erin Bay. Pyefinch(1948), however, stated that roughly 30 days were required between hatching and the appearance of the cyprid larvae. Figures $4 \& 5$ show the two-month interval between the maxima of nauplius and cyprid larvae. However, as the larval stages of Port Erin Bay, and the Jakarta Bay as well, had not been specifically identified, it is possible that those are over-estimates, including more than one species.

The occurrence of cyprids were usually much smaller than nauplii. According to MOORE (1935), the difference is no doubt due in part to mortality and to dispersal of the larvae, and in part to the difference in the larval period of the stages. VESCHER (1928) stated that the free-swimming period of the cyprid lasted from 3 days to 2 weeks or longer.

The abundance of barnacle larvae usually coincided with the abundance of zooplankton in this area (Fig. 3). There were three maxima of zooplankton throughout the periods of observations i.e. April-May 1975, September 1975, and January 1976.

The seasonal variations of barnacle larvae throughout the periods of investigation were as follows (Fig. 6):

Transition Period I (March-April-May 1975)

The barnacle larvae were usually low in number, especially in March. In April, however, the dense population moved to the northern part of the area.

East Monsoon (June-July_August 1975)

At the beginning of this season the great abundance of barnacle larvae was observed at the northern part. In full East Monsoon, a large 
STUDIES ON THE DISTRIBUTION OF BARNACLE LARVAE

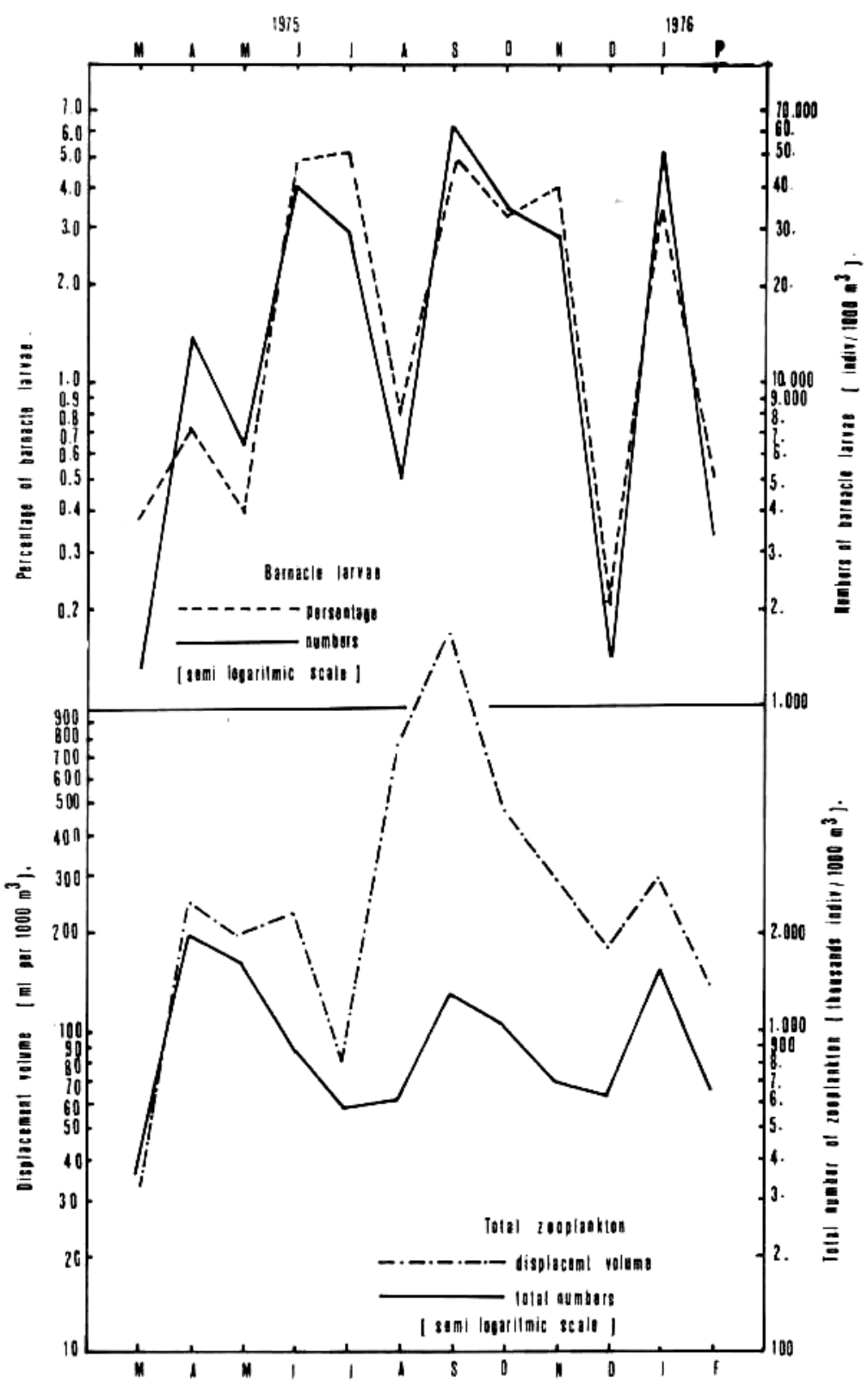

Figure 3. Barnacle larvae and total zooplankton at Muara Karang. 


\section{KASIJAN ROMIMOHTARTO \& OKTO HARYANTO ARINARDI}

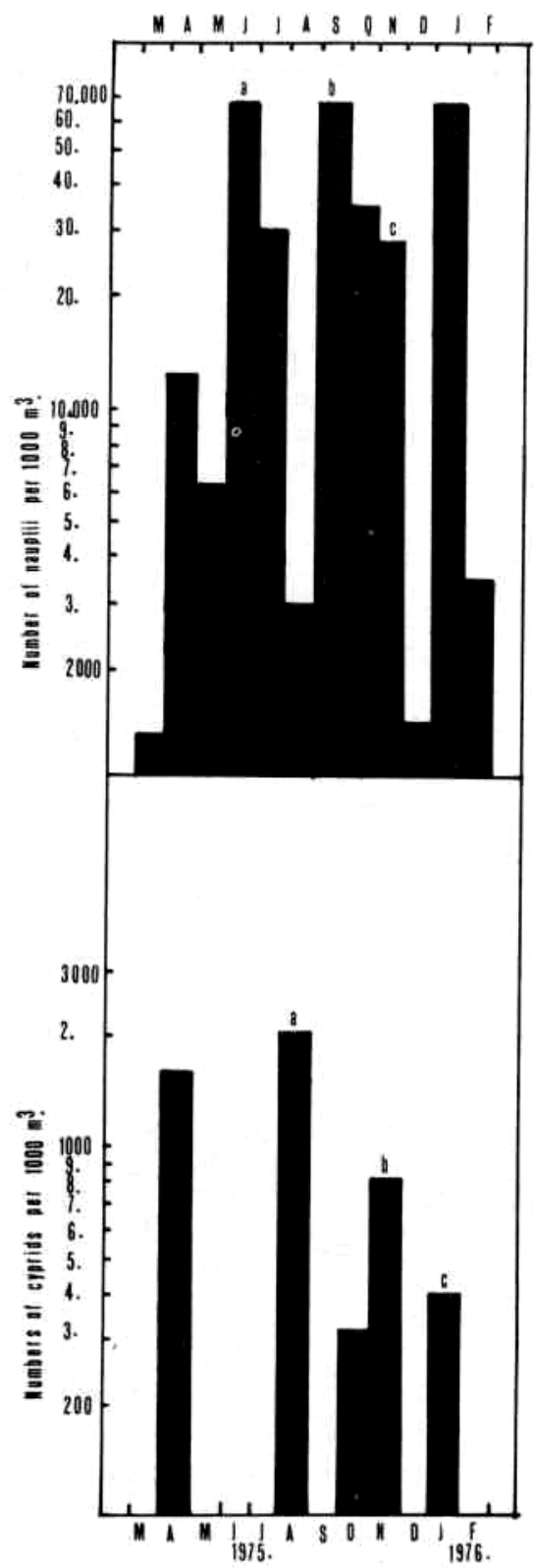

Figure 4. All barnacle nauplii, expressed as average numbers per monthly haul at Muara Karang (in semi logarithmic scale).

Figure 5. All cyprid larvae, expressed as average numbers per monthly haul at Muara Karang (in semi logarithmic scale). 


\section{STUDIES ON THE DISTRIBUTION OF BARNACLE LARVAE}

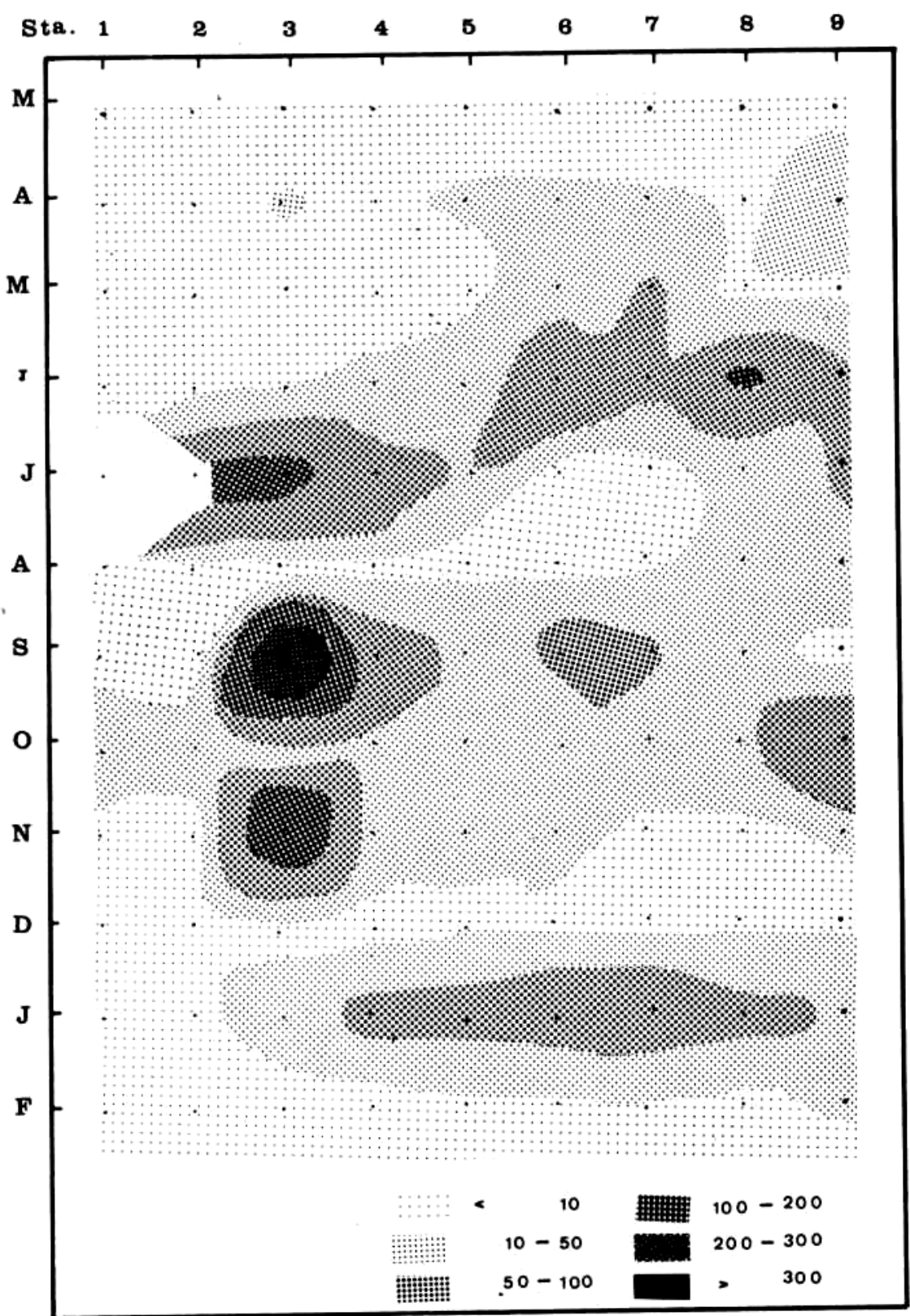

Figure 6. Barnacle larvae distribution with respect to station and month at Muara Karang waters (thousands individual $/ 1000 \mathrm{~m}^{3}$ ). 


\section{KASIJAN ROMIMOHTARTO \& OKTO HARYANTO ARINARDI}

concentration of the larvae was found at the eastern part, near the canal mouth of Sunda Kelapa Harbour.

Transition Period II (September-October-November 1975)

The barnacle larvae were nearly found at every station of sampling, particularly in October, they were seen in relatively great proportion at every station. During this season the dense population was generally observed near the mouth of the canal.

West Monsoon (December 1975-January-February 1976)

At the western part of the area investigated, barnacle larvae were seen to be relatively abundant especially in full West Monsoon. At the end of this season the distribution of larvae was rather homogeneous.

The results of the studies reveal that no evidence of regularly recurring variations of a seasonal nature was seen in the abundance of barnacle larvae in this area. However, in general after the larvae occurred in great abundance, they would gradually decrease to a minimum in the following three or four months, and then reappeared in dense concentration. Furthermore, the barnacle larvae were usually found at a distance from the coast. They would disappear or occur in low quantity farther or closer to the coast. SOEgIARTO et al (1974) also concluded that at Kelapa Dua waters, near Cilegon, the high concentration of barnacle larvae were generally found further off the coast.

The effect of the seston load in the estuarine waters, which consists mostly of sediment, on the distribution of barnacle larvae is very often clear. This could be seen in the Muara Karang waters where during West Monsoon the sediment load was generally high especially at the coastal water, the numbers of barnacle larvae were relatively low. Figure 6 shows that in January 1976 the numbers of barnacle larvae at station 1 and station 2 (close to shore) were minimum. This coincided with a peak of seston load at the two stations.

This is also true for the distribution of barnacle larvae at Cilegon waters (Sumegur Cove). To illustrate the sediment effect on that distribution, the results of the fourth cruise in Cilegon waters on November 1974, whence the seston load at Sumegur Cove was maximum, are presented in Figure 7 and Figure 8 . It can be seen that the numbers of barnacle larvae were minimum at the cove.

\section{Barnacle attachments}

Taking into account only the barnacles attaching on the steel panels which are the most favoured surfaces among the panels submerged, the results of the study indicated that barnacle attachment on steel panels 


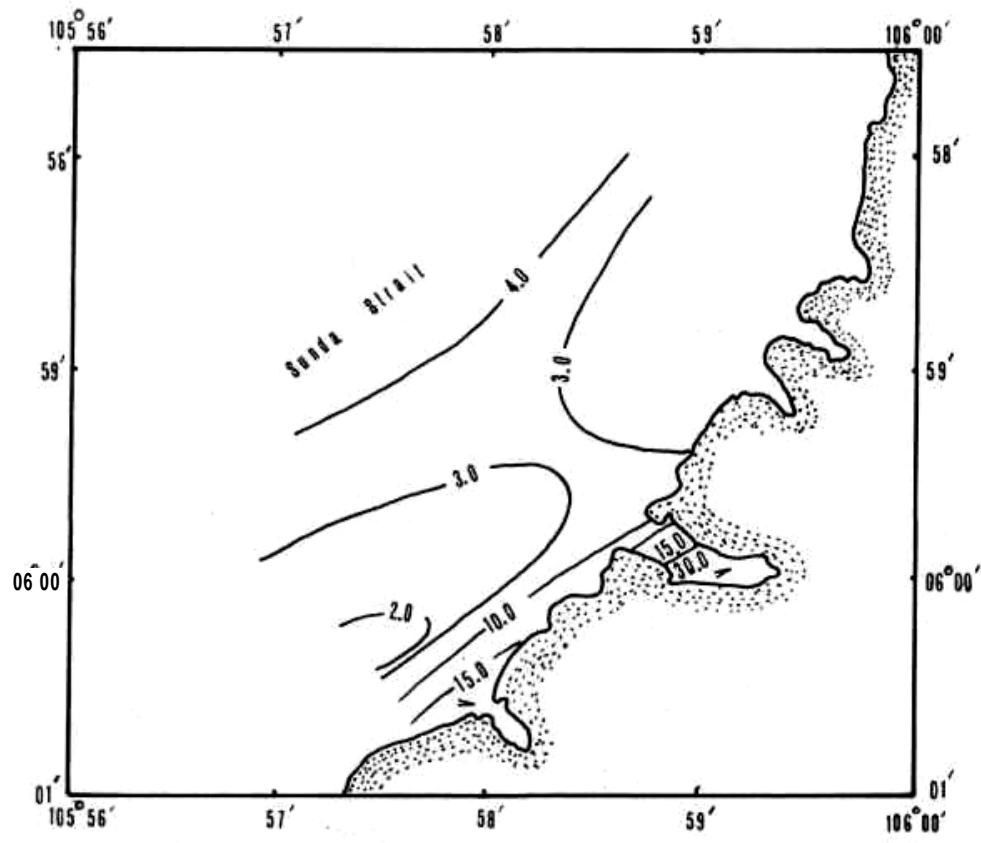

Figure 7. Seston (mg/1), surface layer. Cruise IV, 20-21 November 1974.

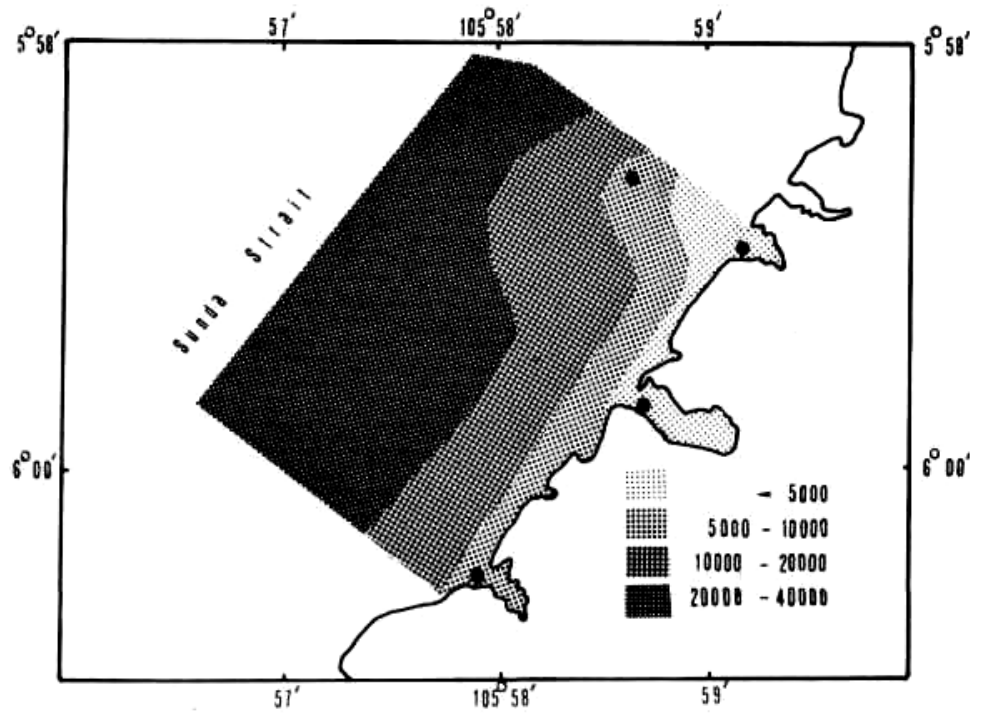

Figure 8. Distribution of barnacle larvae (individual $/ 1000 \mathrm{~m}^{3}$ ). Cilegon Cruise IV, 20 November 1974. 


\section{KASIJAN ROMIMOHTARTO \& OKTO HARYANTO ARINARDI}

occurred throughout the year except in February 1976, when no attachment was observed on all panels (Fig. 9). Generally heavier attachments occurred during the first half of the period (March-April 1975 to July-August 1975), much lighter during the rest of the time until February 1976. Heavy attachment was observed again in March 1976. The period of relatively heavy attachment coincided with the First Transition Period and the East Monsoon which are usually calmer than the period toward West Monsoon.

There is a strong indication that the failure of barnacle attachment and growth especially in February 1976 were due to two factors; sedimentation and wave. This can be indicated by the maximum seston load of Muara Karang River at station 1 and station 2 in January 1976 (Fig. 10), and the maximum wave height in the same month (Fig. 11).

Indirectly the after-effect of the heavy silting on the barnacle attachments can be shown by the fact that the copper pipes used in the experiment which is known to be toxic to barnacles were also fouled, although the number of the attached barnacles on the copper pipes was much smaller than that on the other panels. Maximum number of attached barnacles was found on the inner side in August 1975 (540 ind./900 $\mathrm{cm}^{2}$ ) with maximum diameter of $10.7 \mathrm{~mm}$. As it is known, copper is resistant to fouling. Its resistance is attributed to the solution of the metal (DAVY according to REDFIELD\& WEISS 1948). It is believed that the ions formed on the solution of copper or its salts prevent the attachment of marine organisms by virtue of their poisonous action. Copper did not foul, through contact with a basal metal, when a galvanic couple was formed which prevents the solution of the copper.

The above copper pipes, which had been used in the two previous experiments (in 1974) without being fouled in the last experiment and the fouling organisms could attain relatively large size. This might be due to the occurrence of heavy silting in the area studied which covered almost all submerged panels. The copper pipes were rather thickly coated with "mud" and this may prevent or decrease solution of the copper ion and likewise the toxic effect of the pipes and allowed slime-forming organisms to form slime on the surfaces of the pipes and hence the attachment of barnacle larvae.

The failure of larval settlings due to sedimentation could be shown by the results of the experiment made at Sumegur Cove at station C (Fig. 2). In general the barnacle attachments were less successful in this area. This were indicated by the relatively quite small number of barnacle attached on the panels, maximum 450 ind./900 $\mathrm{cm}^{2}$ (Table I), and by the death of some of the attached barnacles with few or no replacement by new settlings as shown by the decrease in number of attachment on the concrete cube except on the 
STUDIES ON THE DISTRIBUTION OF BARNACLE LARVAE

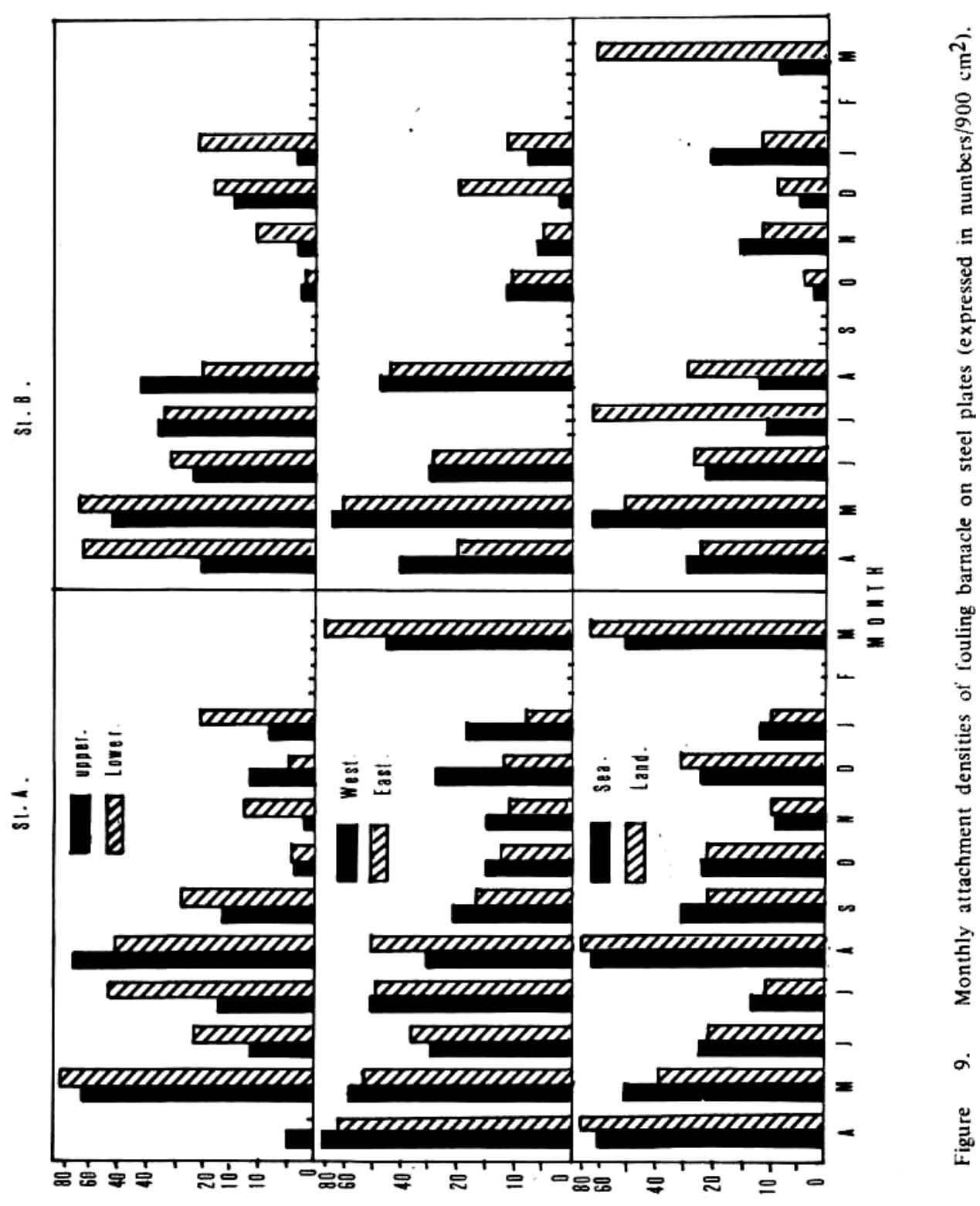

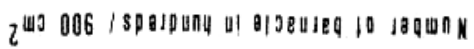


KASIJAN ROMIMOHTARTO \& OKTO HARYANTO ARINARDI

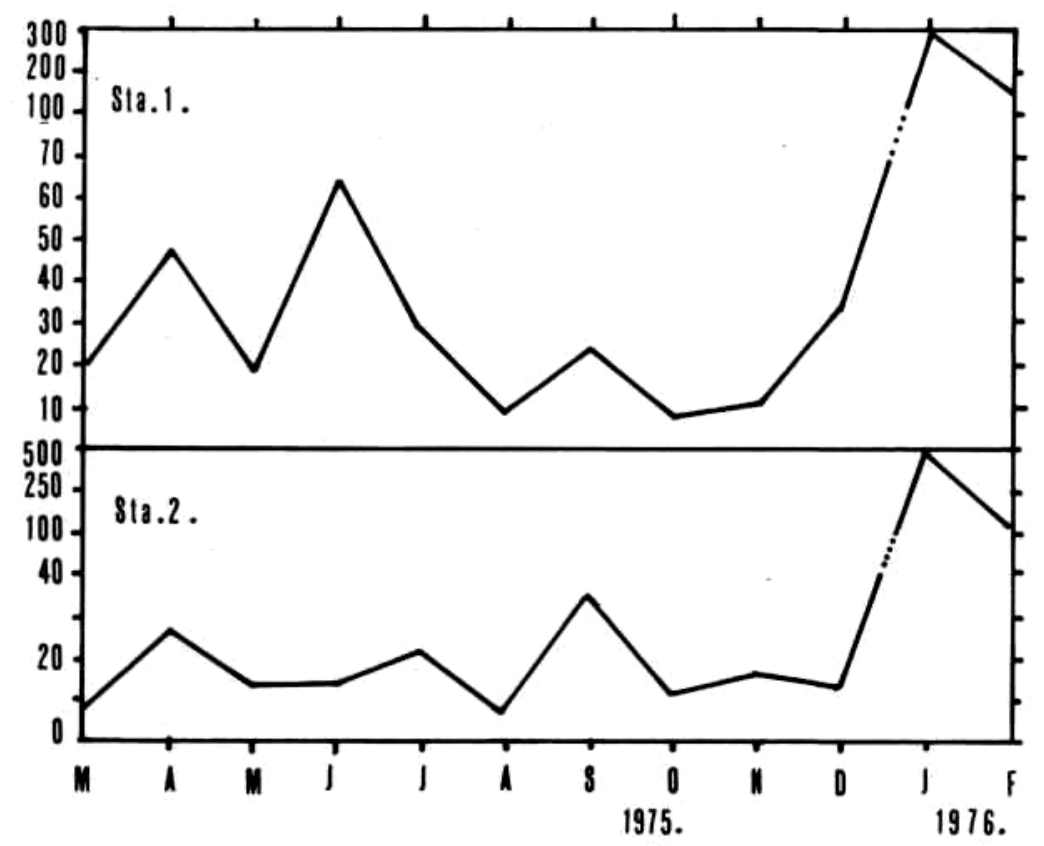

Figure 10. Monthly variation of seston from the sea at station $1-2$.

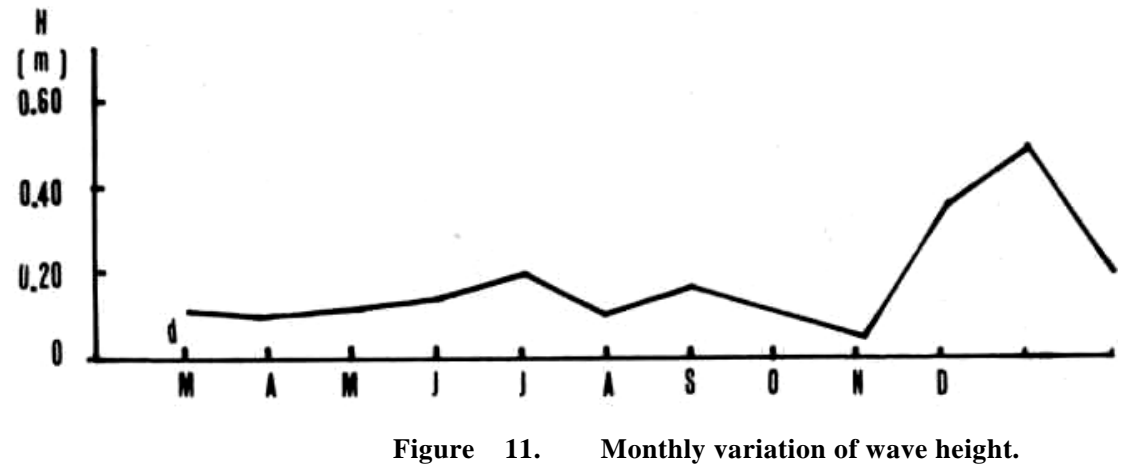


TABLE 1. Attachment rate of barnacles (per $900 \mathrm{~cm}^{2}$ ) on different panels from Sumegur Cove (Station C)

\begin{tabular}{cccccc}
\hline $\begin{array}{c}\text { Name \& position } \\
\text { of panel }\end{array}$ & $\begin{array}{c}\text { Date of } \\
\text { submersion }\end{array}$ & & \multicolumn{4}{c}{ Date of checking } \\
\cline { 3 - 6 } & $26-\mathrm{X}-1974$ & - & 0 & 225 & $\mathrm{X}$ \\
\hline $\begin{array}{c}\text { Steel plate } \\
\text { seaward } \\
\text { landward }\end{array}$ & & - & 0 & 450 & $\mathrm{X}$ \\
$\begin{array}{c}\text { Concrete cube } \\
\text { upper }\end{array}$ & $8-\mathrm{XI}-1974$ & - & - & 20 & 4 \\
$\begin{array}{c}\text { lower } \\
\text { side }\end{array}$ & & - & - & 108 & 296 \\
Brass plate & & - & - & 121 & 21 \\
seaward \\
$\begin{array}{c}\text { landward } \\
\text { Copper pipe } \\
\text { outer } \\
\text { inner }\end{array}$ & $12-\mathrm{X}-1974$ & 0 & 0 & 0 & 0 \\
\hline
\end{tabular}

Note: $-=$ no observation; $0=$ no attachment; $X=$ lost or damaged.

under side of it. Observation made on submerged bamboo pools and other submerged objects found in this cove showed that they were hardly fouled by barnacles or completely devoid of barnacle attachments. Although barnacle larvae were found in a relatively small number $\left(5,000\right.$ ind./10OO $\left.\mathrm{m}^{3}\right)$ in the plankton community in this cove and they successfully settled on submerged objects, most of them seemed to fail to survive. The failure of the barnacle attachments in this cove could probably be due to the unfavourable hydrological condition of this area as shown by high silting process (seston content was relatively high, up to $30 \mathrm{mg} / 1$ at the surface). This might disturb the life of the filting feeding animals such as barnacles.

The above discussion concludes, among other things, that certain environmental factors played important roles in limiting the distribution of barnacle larvae and the success of the barnacle attachment. Two factors, i.e. wave and sediment load, seem to be the most prominent among the other factors in limiting the distribution and the attachment. Among the biological factors which limit or fail the barnacle attachment, the existence of living reef-corals could be mentioned.

It is difficult to correlate the seasonal distribution of the larvae with the density of attachment of the barnacle, without regarding interacting environmental factors such as currents, tides, salinity, light, and some other factors. The present study is still general and does not deal with certain 


\section{KASIJAN ROMIMOHTARTO \& OKTO HARYANTO ARINARDI}

species and certain factors. It is imperative to suggest, therefore, that separate detailed studies of the fouling organisms in the estuarine area should be initiated.

\section{REFERENCES}

BARNES, H. 1950. A note on the barnacle larvae of the Clyde Sea area as sampled by the Hardy Continuous Plankton Recorder. Jour. Mar. Biol. Assoc. 29 (1): 73 - 80.

CHUA, T. E. 1970. A preliminary study on the plankton of the Ponggol Estuary. Hydrobiologia 35 (2): $254-272$.

FLEMMING, R. H. 1948. Physical characteristics of the inshore environment. Jour. Mar. Res. 7: 483 - 489.

LEMBAGA OSEANOLOGI NAS1ONAL 1974. Final report on the first stage of the Oceanological investigation and survey in connection with the Muara Karang Steam Power Station Project. Chapter III. Biological Survey: LON - LIPI, Jakarta: III 1 - 44.

MOORE, H.B. 1935. The biology of Balanus balanoides III. The soft parts. Jour. Mar. Biol. Assoc. 20: 263 277.

PRASAD, R. R. 1954. The characteristics of marine plankton at inshore station in the Gulf of Mannar near Mandapan. Ind. Jour. Fish. 1 (1): 1 - 36.

PYEFINCH, K. A. 1948. Notes on the biology of cirripedes. Jour. Mar. Biol. Assoc. 27: 464 - 503.

REDFIELD," A.C. and CM. WEISS 1948. The resistance of metallic silver to marine fouling. Biol. Bull 94(1): $25-28$.

SOEgIARTO, A., K. ROMIMOHTARTO, S. BIROWO, A. NONTJ1, KASTORO, BURHANUDDIN, D. P. PRASENO, SUKARNO, A.G. ILAHUDE and I. SUPANGAT 1974. Final report on the first phase of the oceanological investigation and survey in connection with a plan to construct an Electric Steam Power Generator at Kelapa Dua, Cilegon. Chapter III. Biological Survey: LON - LIPI, Jakarta: $35-72$.

THAM, A. K. 1953. A preliminary study of the physical, chemical and biological characteristics of Singapore Straits. Col. Off Fish. Publ 1 (4): 1 - 65.

VISSCHER, J. P. 1928. Reactions of the cyprid larvae of barnacles at the time of attachment. Biol. Bull, Woods Hole 54: 327 - 335 .

WICKSTEAD, J. H. 1958. A survey of the larger zooplankton of Singapore Straits. Jour, du Cons. 23 (3): 340 $-353$.

WICKSTEAD, J.H. 1965. An introduction to the study of tropical plankton. Hutch. Trop. Monogr., London: $1-160$. 